\title{
PENGARUH PENYULUHAN PAJAK TERHADAP SIKAP MAHASISWA DI JAKARTA
}

\author{
Retno Ekasari \\ Institut Ilmu Sosial dan Manajemen STIAMI \\ E-mail: ennoaksyamala06@gmail.com
}

\begin{abstract}
The purpose of this research was to analyze the effect of tax education conducted by the Director General of Taxes on student attitudes. This research used explanatory quantitative research methods by using a survey to 134 respondents. Theories used are Schiffman \& Kanuk's basic communication theory / model, counseling theories, persuasive communication theory from Petty \& Otcioppo and Attitude theory from Hovland and Janis \& Kelley. The results of data processing used the Path Analysis method. The results showed that the source factor did not significantly influence the internal intermediary process. The message factor has a significant effect on the internal intermediary process. The internal intermediary process significantly influences attitude. This research also found that respondents' statements about the credibility of extension workers were quite good. This can be seen from the statements of respondents that the instructor has complete knowledge, masters the material presented, has experience in taxation, can be trusted, and objective in delivering the material. The message factor influences the internal intermediary process. In counseling conducted by the Director General of Taxes, the message factor which consists of the validity of the message contents, the actualization of the message contents, this package of messages affect the attitude of students. The more valid and actual the material presented, the more it gets the attention of students. Tax counseling conducted by the Director General of Taxes can affect student attitudes.
\end{abstract}

Keywords: Tax education; communication; message; student attitude

\begin{abstract}
Abstrak
Tujuan penelitian ini untuk menganalisis pengaruh penyuluhan pajak yang telah dilakukan oleh Dirjen Pajak terhadap sikap mahasiswa. Penelitian ini menggunakan metode penelitian kuantitatif eksplanatif dengan menggunakan survey terhadap 134 responden. Teori yang digunakan adalah teori/model komunikasi dasar Schiffman \& Kanuk, teori-teori penyuluhan, teori komunikasi persuasif dari Petty \& Otcioppo dan teori Sikap dari Hovland serta Janis \& Kelley. Hasil pengolahan data menggunakan metode Path Analysis. Hasil penelitian menunjukan bahwa faktor sumber tidak berpengaruh signifikan terhadap proses perantara internal. Faktor pesan berpengaruh signifikan terhadap proses perantara internal. Proses perantara internal berpengaruh signifikan terhadap sikap. Penelitian ini juga menemukan bahwa pernyatan-pernyataan responden terhadap kredibilitas penyuluh cukup baik. Ini terlihat dari pernyataan-pernyataan responden bahwa penyuluh memiliki pengetahuan yang lengkap, menguasai materi yang disampaikan, memiliki pengalaman di bidang perpajakan, dapat dipercaya, dan objektif dalam penyampaian materi. Faktor pesan berpengaruh terhadap proses perantara internal. Pada penyuluhan yang dilakukan oleh Dirjen Pajak, faktor pesan yang terdiri dari validitas isi pesan, aktualisasi isi pesan, kemasan ini pesan berpengaruh terhadap sikap mahasiswa. Semakin valid dan aktual materi yang disampaikan, semakin mendapat perhatian mahasiswa. Penyuluhan pajak yang dilakukan oleh Dirjen Pajak dapat memengaruhi sikap mahasiswa.
\end{abstract}

Kata kunci: Penyuluhan pajak; komunikasi; pesan; sikap mahasiswa 


\section{PENDAHULUAN}

Negara Indonesia adalah negara hukum berdasarkan Pancasila dan Undang-Undang dasar 1945 yang sangat menjunjung tinggi hak dan kewajiban setiap orang. Salah satu wujud kewajiban kenegaraan sebagai peran serta dalam pembiayaan negara dan pembangunan adalah perpajakan. Pajak bagi sebuah negara adalah kemutlakan. Sebagai sumber utama penerimaan negara maka pajak mempunyai peranan yang sangat strategis bagi kelangsungan pembangunan suatu negara. Tanpa adanya pemasukan pajak, negara tidak bisa berbuat apa-apa. Di Indonesia, pajak sangat besar peranannya dalam menjalankan roda pemerintahan karena merupakan sumber utama penghasilan negara selain penerimaan dari sumber migas dan non migas. Apabila kita mengamati perkembangan posisi APBN dari waktu ke waktu, posisi dan peranan pajak bagi pemenuhan kebutuhan negara menjadi makin vital. Pendapatan dari sektor non pajak seperti minyak, basil tambang, hutan dan sumber daya alam lainnya hampir tidak bisa diharapkan lagi.

Pentingnya pendapatan dari pajak ini dapat dilihat dalam trend persentase sumbangan perolehan pajak bagi APBN yang terus meningkat dari tahun ke tahun. Pada tahun 2001, kontribusi perolehan pajak bagi APBN sebesar 61,7\% naik menjadi 70, $1 \%$ pada APBN tahun anggaran 2002. Sumbangan pajak bagi anggaran mengalami peningkatan lagi pada tahun anggaran 2003, yaitu sebesar 75,6 \%. Pada APBN tahun 2004, sumbangan pajak meningkat lagi sebesar $79 \%$ (Transparency International Indonesia, Press release, 2005) karena itu wajar jika pemerintah terus berupaya menggali berbagai potensi tax coverage (lingkup/cakupan pajak) sekaligus menekankan tax compliance (kepatuhan pajak) dari masyarakat sebagai elemen vitalnya (Sasqart, 2004) Melihat sejarah perpajakan di Indonesia yaitu sejak masa prakolonial, pemerintah telah melakukan banyak sekali perombakan sistem perpajakan (Salamun, 1990 : 27).

Sejarah perpajakan yang panjang itu juga telah melahirkan persepsi umum, baik terhadap sistem perpajakan maupun terhadap para pelaksananya, yang pada akhirnya membentuk citra di masyarakat. Persepsi masyarakat tentang citra pajak tersebut berbentuk positif maupun negatif, namun rasanya sulit sekali dipungkiri bahwa citra perpajakan dan aparatnya selama ini lebih berkembang ke arah citra yang negatif (Salamon, 1990: 27). Citra negatif itu bukanlah hal yang berkembang tanpa alasan, karena sudah menjadi rahasia umum bahwa ada orang-orang yang berusaha mencari keuntungan sendiri, terutama dalam proses negosisasi penetapan ataupun penghitungan besarnya pajak terhadap Wajib Pajak (Salamon, 1990: 30). Hal inilah yang menyebabkan rakyat belum sukarela membayar pajak. Adanya citra yang berkembang di tengah-tengah masyarakat, bahwa membayar pajak untuk orang-orang pajak. Citra negatif yang berkembang ini menyulitkan pemerintah karena pada akhirnya akan menghambat proses pembangunan. Dalam membayar pajak, pemerintah selalu mengkampanyekan bahwa membayar pajak sepenuhnya untuk keperluan pembangunan. Namun sampai saat ini pikiran negatif masyarakat terhadap pihak pajak masih belum dapat dihilangkan.

Kesadaran masyarakat untuk taat pajak merupakan kewajiban bagi segenap Wajib Pajak dan masyarakat. Intensitas sosialisasi yang lebih tinggi serta sikap proaktif fiskus dalam memberikan bimbingan, penyuluhan, pengarahan kepada Wajib Pajak dan masyarakat secara luas akan arti penting realisasi dan pajak bagi pembangunan bangsa diharapkan menjadi pilar kesadaran untuk taat pajak. Untuk itu diperlukan pendekatan penyuluhan dan sosialisasi efektif agar dapat menciptakan masyarakat sadar pajak. Penyuluhan perpajakan kepada masyarakat merupakan ujung tombak yang dilakukan untuk meningkatkan kesadaran masyarakat terutama kewajibannya dalam membayar pajak.

Tujuan penyuluhan perpajakan bukan hanya untuk meningkatkan jumlah Wajib Pajak dan penerimaan pajak dari tahun ke 
tahun semata. Yang utama adalah meningkatkan kesadaran membayar pajak di kalangan masyarakat sehingga pajak yang dibayarkan tadi sesuai dengan tuntutan masyarakat terhadap pembangunan ekonomi khususnya, dan pembangunan nasional pada umumnya. Tujuan lainnya adalah menanamkan kesadaran dan pemahaman pajak sejak dini khususnya bagi generasi muda sehingga diharapkan pajak tidak lagi menjadi hal yang ditakuti dan dihindari oleh masyarakat.

Pemerintah dalam hal ini Ditjen Pajak melakukan berbagai hal agar tujuan tersebut dapat tercapai. Di antaranya adalah dengan membuat program-program penyuluhan yang mendukung agar penyuluhan yang dilakukan tepat sasaran. Misalnya, dengan mengadakan pemilihan Arjuna-Srikandi pajak sebagai duta pajak yang bisa menginformasikan masalah pajak dengan sikap dan cara yang baik. Selain itu mengadakan tax road show ke sekolahsekolah dan juga perguruan tinggi dengan tujuan mengenalkan pajak sejak dini kepada generasi muda dan juga untuk meninggkatkan kesadaran arti penting peranan pajak bagi pembangunan. Topik yang disosilisasikan misalnya dengan mengenalkan pengertian pajak, jenis-jenis pajak, pengertian tentang Wajib pajak, pengertian NPWP, manfaat pajak dan lain sebagainya. Ditjen Pajak pun melakukan sosialisasi ke berbagai Departemen seperti Departemen Dalam Negeri, Departemen Kesehatan, Departemen Pendidikan Nasional, Departemen Pemberdayaan Wanita, Departemen Perikanan dan lain-lain. Pada masyarakat umum dengan mengadakan penyuluhan kepada ibu-ibu Dharma Wanita, mengadakan acara Tac Tic Tax yang ditayangkan salah satu stasiun televisi swasta, dan lain-lain.

Upaya-upaya yang telah dilakukan pemerintah untuk menciptakan masyarakat agar memiliki apresiasi yang baik terhadap kewajiban membayar pajak, seharusnya menciptakan masyarakat sadar dan peduli pajak. Namun, kesadaran masyarakat untuk membayar pajak masih tergolong rendah. Ironisnya, fenomena ini tidak saja dijumpai di kalangan masyarakat berpenghasilan rendah yang memiliki keterbatasan wawasan dan pengetahuan soal pajak, tapi juga di kalangan masyarakat atas yang lebih cerdas dengan penghasilan yang lebih baik serta paham fungsi dan peran pajak.

Dengan Penyuluhan pajak yang berkesinamungan diharapkan dapat membentuk sebuah masyarakat sadar membayar pajak, memiliki kepatuhan (complience) yang memadai, dan komitmen moral terhadap kewajiban perpajakannya (Jurnal Perpajakan Indonesia, 2003 : 38). Berdasarkan hal di atas maka penulis tertarik untuk melakukan analisis pengaruh penyuluhan pajak terhadap sikap mahasiswa akan pajak sehingga dapat diketahui pengaruh sumber dan pesan terhadap sikap mahasiswa.

\section{KERANGKA KONSEPTUAL}

Teori yang disajikan dimaksudkan sebagai bahan acuan atau rujukan dalam menganalisa permasalahan.

Menurut Van den Ban (1999: 25), penyuluhan adalah:

"Penyuluhan merupakan keterlibatan seseorang untuk melakukan komunikasi informasi secara sadar dengan tujuan membantu sesamanya memberikan pendapat sehingga bisa membuat keputusan yang benar"

Mardikanto (dalam Rejeki dan Herawati, 1999 : 10) tentang penyuluhan pertanian, penyuluhan dapat dipahami sebagai sebuah proses. Ada empat proses untuk memahami penyuluhan, yaitu:

a. Penyuluhan sebagai proses penyebaran informasi:

Melalui penyuluhan akan terjadi penyebarluasan informasi. Informasi yang dimaksud dapat terkait dengan materi, sumber informasi maupun alur informasi.

b. Penyuluhan sebagai proses penerangan:

Penyuluhan dapat diartikan sebagai proses untuk memberikan penerangan kepada masyarakat tentang sesuatu "yang belum diketahui" (dengan jelas) untuk melaksanakan/diterapkan yang ingin dicapai melalui proses pembangunan (adaptasi dari mardikanto, dalam Rejeki dan Herawati 1999: 10). Dalam memberikan penyuluhan tersebut seorang juru penerang/penyuluh perlu 
melakukannya secara terus - menerus sampai sasarannya mampu memahami, menghayati dan akhirnya melaksanakan yang disuluhkannya.

c. Penyuluhan sebagai proses perubahan perilaku:

Tujuan dari suatu penyuluhan adalah terjadinya perubahan perilaku tidak sekedar memberitahu atau menerangkan. Perubahan perilaku yang dimaksudkan menyangkut pengetahuan, sikap dan keterampilan dari sasaran komunikasi

d. Penyuluhan sebagai proses pendidikan: Perubahan perilaku dilakukan melalui pendidikan. Dengan demikian penyuluhan tersebut mengandung:

- Menyampaikan

pemahaman/pengetahuan tentang segala sesuatu yang lebih baik atau bermanfaat

- Dilakukan tanpa adanya paksaan dari pihak manapun

- Adanya kemampuan untuk menyediakan sumber daya yang diperlukan. e. Penyuluhan sebagai proses rekayasa sosial.

Penyuluhan adalah proses transformasi sosial, dimana ada upaya-upaya yang dilakukan oleh para penyuluh untuk mengadakan transfer nilai-nilai sosial dari suatu generasi ke generasi berikutnya.

Komunikasi merupakan kegiatan yang tidak dapat dipisahkan dari kehidupan manusia. Komunikasi dapat mempengaruhi seluruh kehidupan kita, bahkan dapat dikatakan komunikasi merupakan kebutuhan hakiki bagi kehidupan manusia. Melalui komunikasi diharapkan dapat disampaikan informasi yang tepat guna, tepat sasaran, dan.tepat waktu sehingga dapat menumbuhkan aspek edukasi. Komunikasi juga dapat dijadikan sebagai kerangka acuan untuk membentuk pendapat, menentukan sikap, dan memutuskan tindakan, sebagian besar didapatkan dari informasi mengenai komunikasi.

Untuk lebih jelasnya, di bawah ini digambarkan Metode Komunikasi yaitu Model Komunikasi Dasar :

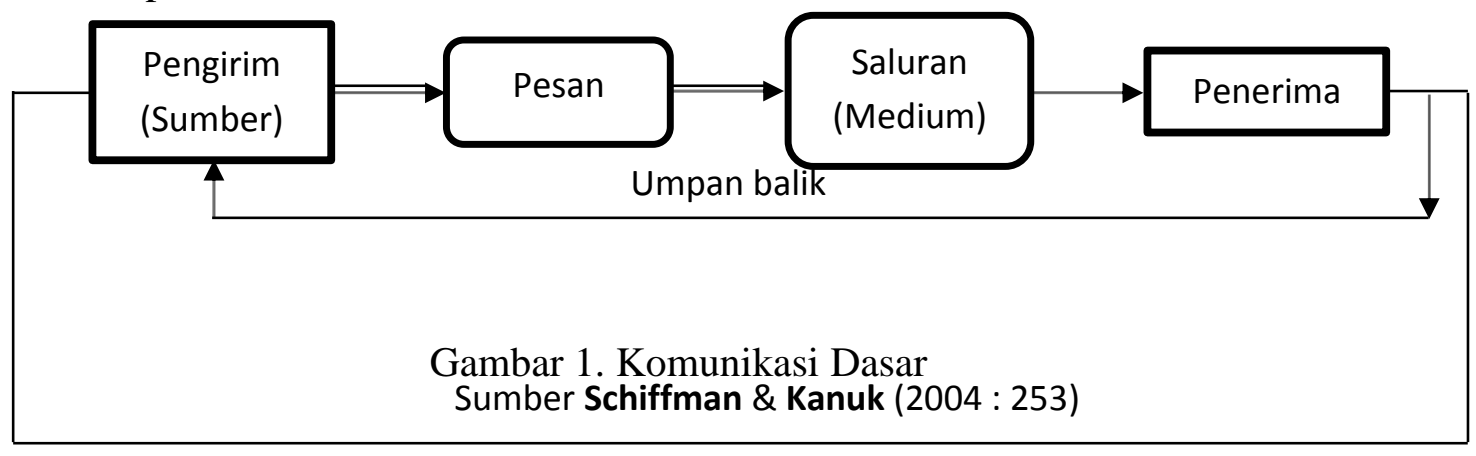

Komunikator sebagai pemrakarsa komunikasi dapat merupakan sumber formal atau informal, Sumber komunikasi formal dapat berupa organisasi komersial maupun organisasi nirlaba, sumber informal dapat berasal dari orang tua, teman, guru dll (Schiffman \& Kanuk, 2004 : 252). Agar komunikasi efektif, proses penyandian oleh komunikator harus bertautan dengan proses pengawasan dan oleh komunikan. Wilbur Schramm (Effendy, 2003: 19) melihat pesan sebagai tanda esensial yang harus dikenal oleh komunikan. Semakin tumpang tindih bidang pengalaman (field of experience) komunikator dengan bidang pengalaman komunikan, akan semakin efektif pesan yang dikomunikasikan. Komunikator akan dapat menyandi dan komunikan akan dapat mengawasandi hanya dalam istilah-istilah pengalaman yang dimiliki masing-masing. Memang ini merupakan beban bagi Komunikator dari strata sosial yang satu yang ingin berkomunikasi secara efektif dengan komunikan dari strata sosial yang lain. Akan tetapi, dalam teori komunikasi dikenal istilah emphaty, yang berarti kemampuan memproyeksikan diri kepada peranan orang lain. Jadi meskipun antara komunikator dan komunikan terdapat perbedaan kedudukan, jenis pekerjaan, agama, suku, bangsa, tingkat pendidikan, ideologi, dan lain-lain, jika komunikator bersikap empatik, maka komunikasi tidak akan gagal (Effendy, 2003: 19). 
Penelitian menunjukkan (Azwar, 2005: 72 - 76) bahwa efektivitas komunikator dalam menyampaikan pesannya (dalam hal pesan yang bertujuan untuk pengubahan sikap) akan bergantung pada beberapa hal, yang telah diteliti secara ekstensif, antara lain adalah kredibilitas (credibility), daya tarik (attractiveness), dan kekuatan (power) komunikator itu sendiri.

a. Kredibilitas (Credibility)

Kredibilitas adalah seperangkat persepsi komunikan tentang sifat-sifat komunikator (Rakhmat, 2003: 257). Menurut Hovland, Kredibilitas merupakan kerangka perseptual khalayak tentang komunikator dan bukan karakteristik komunikator itu sendiri. Karenanya kredibilitas yang dimiliki komunikator harus disesuaikan dengan khalayak yang akan dituju (Venus, 2004: 44). Kredibilitas komunikator dilandasi oleh dua karakter penting, yaitu keahlian dan kepercayaan (trustworthiness).

Keahlian berhubungan dengan penilaian dimana sumber dianggap berpengetahuan, cerdas, berpengalaman, memiliki kewenangan tertentu dan menguasai keahlian yang bisa diandalkan (Venus, 2004: 60). Untuk dapat dikatakan ahli, seseorang tidak perlu memiliki semua kualitas diatas. Satu atau dua sifat saja umumnya dianggap sudah mencukupi. Keahlian seorang sumber mungkin akan efektif ketika pertahanan psikologis kita sedang turun, ketika kita tidak perduli terhadap isu atau kita tidak berpikir bahwa kita mempunyai kemampuan untuk membandingkan argumentasi pesan. Demikian pula keterlibatan yang rendah, kemampuan penerimaan yang rendah juga mudah dijadikan sasaran bagi seorang sumber yang pandai membaca karakteristik khalayak. Pengalaman sumber tentang topik yang dibicarakan termasuk dalam kategori keahlian juga. Pengalaman tersimpan dalam memori seseorang dan memori ini akan dipanggil dan digunakan untuk memecahkan masalahmasalah sejenis yang dihadapinya. Pengalaman ini berkaitan juga dengan intensitas keterlibatan seseorang dalam melakukan suatu pekerjaan atau hal lainnya. Disini berlaku anggapan bahwa makin tinggi keterlibatan seseorang maka makin tinggi pula kredibilitas yang bersangkutan (Venus, 2004: 60-62)

Kepercayaan (trustworthiness), yaitu: kesan komunikan tentang komunikator yang berkaitan dengan wataknya (Rakhmat, 2003: 260). Kepercayaan berkaitan dengan penilaian khalayak bahwa sumber informasi dianggap tulus, jujur, bijak dan adil, objektif, memiliki integritas pribadi, serta memiliki tanggung jawab sosial yang tinggi (Venus, 2004: 57). Pesan yang diorganisasikan dan disampaikan dengan baik belum tentu cukup untuk mempengaruhi khalayak. Diperlukan juga komunikator yang terpercaya untuk menyampaikan pesan tersebut (Venus, 2004: 43). Larson (dalam Venus, 2004 : 43-44) mengatakan bahwa semua bukti didunia menunjukkan bahwa pesan yang dirancang dan disampaikan dengan sempurna tidak akan dapat membawa perubahan perilaku jika khalayak tidak mempercayai komunikator. Motif yang ada dibelakang perilaku individu menjadi dasar proses psikologis yang berbeda, yang terjadi sewaktu seseorang menerima perubahan sikap yang disugestikan kepadanya. Apabila seseorang dimotivasi oleh keinginan mencari kebenaran atau pengetahuan, maka individu tersebut akan lebih mudah terbujuk atau tersugesti apabila komunikatonya adalah seseorang yang dipercayai dan dianggap kompeten mengenai hal yang ingin ia ketahui atau bila komunikatomya adalah orang yang dipercayainya (trustworthy).

Menurut Johnston (dalam Venus, 2004: 57-58) keterpercayaan atau kejujuran sumber banyak bergantung pada persepsi khalayak tentang maksud tindakan Sumber. Jika khalayak menilai bahwa tindakan atau ucapan sumber didasari motif untuk mengambil keuntungan sepihak, inaka ia akan inenjadi kurang persuasif ketimbang sumber yang dipersepsi dan tidak memiliki kepentingan pribadi. Jadi khalayak akan menolak pesan-pesan yang terlihat hanya mementingkan atau mengusahakan kepentingan orang yang mengungkapka $n$ nya. Hal seperti ini akan membuat sebuah sumber informasi dianggap tidak dapat dipercaya dan orang akan memberikan respon 
skeptis terhadap pesan yang berasal dari sumber informasi yang tidak memiliki trustworthiness. Venus (2004; 57) berpendapat bahwa khalayak akan menilai apakah komunikator dapat dipercaya atau apakah secara moral mereka dapat diandalkan. Penilaian yang dilakukan umumnya berpatoan pada perilaku sumber pada masa lalu dan dugaan khalayak tentang perilakunya pada saat sekarang. Konsistensi juga merupakan salah satu penilaian keterpercayaan. Khalayak akan cenderung mempertimbangkan perilaku yang konsisten sebagai sesuatu yang bisa dipercaya (Venus, 2004: 58) Pada sisi lain, sikap dapat diubah oleh komunikator yang walaupun bukan seorang ahli dalam bidang yang bersangkutan sebagai objek sikap akan tetapi merupakan figur yang dipercayai oleh individu.

Penerimaan seseorang terhadap sebuah pesan bergantung kepada kredibilitas sumber yang mengirimkan pesan, tersebut. Makin tinggi tingkat kredibilitas sumber, makin besar pula kemampua $\mathrm{n}$ sumber tersebut dalam mempengaruhi khalayak (Bettinghaus dalam Venus 2004: 57) Dalam jangka panjang, efek kredibilitas kom11nikator sebagai sumber pesan dapat hilang perlahan-lahan. Orang mungkin masih akan mengingat isi pesan yang akan diterimanya akan tetapi lupa sama sekali siapa sumber pesan tersebut, keadaan ini disebut sleeper effect (Azwar, 2005: 72-74), gejala ini menurut sebuah riset (Schiffman \& Kanuk, 2004; 258) menunjukkan bahwa baik pengaruh kredibilitas yang positif maupun yang negatif cenderung lenyap sekitar 6 minggu.

Secara umum, saluran komunikasi dapat dibagi menjadi 2 jenis, yaitu saluran komunikasi impersonal yaitu biasa disebutdengan media massa dan interpersonal yaitu komunikasi secara langsung yang terjadi antar dua orang atau lebih misalnya saja melalui surat, telepon, on-line dan lain-lain (Schiffman \& Kanuk, 2004:253). Pengirim pesan akan memilih saluran-saluran itu, bergantung pada situasi, tujuan yang hendak dicapai dan jumlah penerima pesan yang dihadapi (Mulyana, 2004:64).
Kegiatan Penyuluhan Pajak memiliki andil besar dalam mensukseskan sosialisasi pajak keseluruh Wajib Pajak. Penyuluhan melalui berbagai media seperti media cetak, elektronik, spanduk, baliho dan sejenisnya termasuk vidiotron serta berbagai seminar pajak telah dilakukan oleh Dirjen Pajak. Berbagai media tersebut diliarapkan mampu roenggugah kesadaran masyarakat untuk patuh terhadap pajak dan membawa pesan moral terhadap pentingnya pajak bagi negara.

Sasaran utama dari penyuluhan pajak adalah (Panduan Materi Penunjang Penyuluhan Perpajakan, 1992: 29) sasaran yang bertujuan untuk mempengaruhi secara langsung anggota masyarakat yang disuluh agar mau mengubah cara berpikir dan berperilaku, yaitu masyarakat pada umumnya, masyarakat wajib pajak dan aparatur negara. Sasaran pendukung adalah sasaran yang diharapkan akan mendukung penyebarluasan informasi perpajakan untuk mempengaruhi anggota masyarakat agar bersedia menyebarluaskan dan menciptakan citra perpajakan yang baik. Yang termasuk dalam sasaran pendukung antara lain adalah konsultan pajak, instansi pemerintah baik Departemen maupun Lembaga non Departemen, lembaga kemasyarakatan, tokoh masyarakat, tokoh agama, cendekiawan dan sebagainya

Susanto (dalam Azwar, 2002 : 63) menyebutkan bahwa suatu komunikasi dikatakan berhasil mengubah sikap dan tindakan seseorang atau berhasil memperoleh persetujuan dari komunikan terhadap apa yang dimaksud oleh konmnikator, dan salah satu cara untuk mengubah sikap dan perilaku orang lain secara sukarela adalah melalui komunikasi persuasif.

Hovland, dkk (dalam Sumartono, 2002: 63) mendefinisikan komunikasi persuasif yaitu sebagai:

"Suatu proses dimana individu (komunikator) memberikan rangsangan (secara verbal) untuk mengubab individu lainnya (audience)"

Menurut Saifuddin Azwar (2005 : 61--62) Persuasi merupakan: 
"Usaha pengubaban sikap individu dengan memasukkan ide, pikiran, pendapat dan fakta baru lewat pesanpesan komunikatif. Pesan yang disampaikan dengan sengaja dimaksudkan untuk menimbulkan kontradiksi dan inkonsistensi diantara komponen sikap individu atau diantara sikap dan perilakunya sehingga mengganggu kestabilan sikap dan membuka peluang terjadinya perubahan yang diinginkan ".

Sikap adalah suatu bangun psikologis. Sikap merupak:an konsep yang paling penting dalam psikologi sosial dan paling banyak: didefinisikan (Rakhmat, 2005: 39). Secara historis istilah sikap digunakan pertama kali oleh Herbert Spencer di tahun 1982 yang pada saat itu diartikan olehnya sebagai status mental seseorang (dalam Azwar, 1995: 3).

Sikap menentukan jenis atau tabiat tingkah laku dalam hubungannya dengan perangsang yang relevan, orang-orang atau kejadian. Dapat dikatakan bahwa sikap merupakan faktor internal, tetapi tidak semua faktor internal adalah sikap. Ciri-ciri sikap menurut Ahmadi (1991: 178-179) adalah sebagai berikut:
1. Sikap adalah sesuatu yang dipelajari (leamability)

Sikap merupakan basil dari belajar.

2. Memiliki kestabilan (stabif)

Sikap bermula dari dipelajari kemudian menjadi lebih kuat, tetap dan stabil melalui pengalaman.

3. Personal Societal Significance

Melibatkan hubungan antara seseorang dengan orang lain dan juga antara orangorang dan barang atau situasi.

4. Berisi kognisi dan afeksi

Komponen kognisi dari sikap adalah berisi informasi yang faktual.

5. Approach-Avoidence Directionally

Bila seseorang memiliki sikap yang favorable terhadap sesuatu objek, mereka akan mendekati dan membantunya juga sebaliknya.

Hovland dan kawan-kawannya (dalam Azwar, 2005: 62) melakukan penelitian faktor-faktor yang dapat mempengaruhi komunikasi persuasif, dalam penelitiannya tersebut, asumsi dasar yang melandasi studi Hovland dan kawan-kawannya adalah anggapan bahwa efek suatu komunikasi tertentu yang berupa perubahan sikap akan tergantung pada sejauh mana komunikasi itu diperhatikan dipahami, dan diterima. Langkah ini dapat disajikan pada :

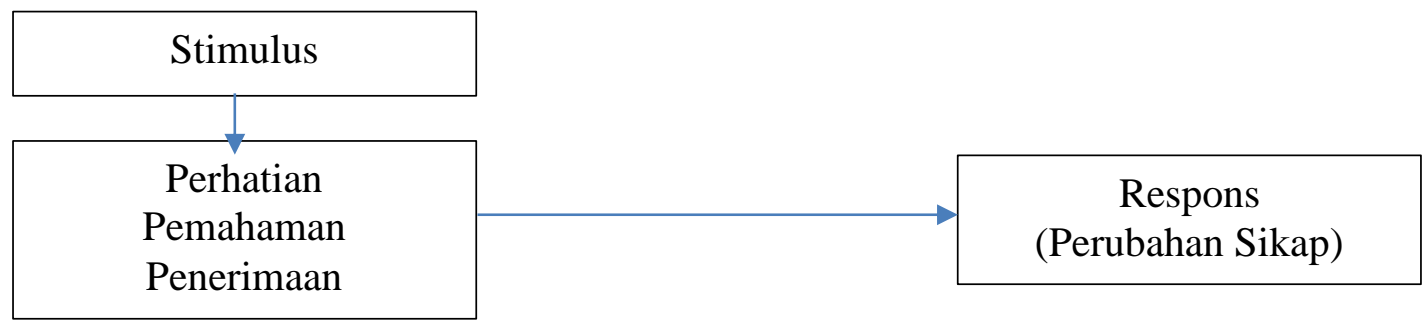

Gambar 2. Langkah-langkah Perubahan Sikap menurut Model Hovland, Janis, \& Kelley 1953, (dalam Azwar, 2005 : 63)

Salah satu aspek yang sangat penting guna memahami sikap dan perilaku manusia adalah masalah pengungkapan (assessment) atau pengukuran (measurement) sikap. Umumnya, sikap dimengerti dalam bentuk pernyataan seberapa positif atau negatifnya terhadap suatu objek sikap. Padahal sikap dapat diungkapkan dan dipahami dari dimensi yang lain. Sax, dalam bukunya yang berjudul "Principles of Educational and Psychological
Measurement and Evaluation" pada tahun 1980, menunjukkan beberapa karakteristik (dimensi) sikap yaitu arah, intensitas, keluasan, konsistensi, dan spontanitasnya. Berikut akan kita uraikan dimensi-dimensi tersebut satu persatu :

\section{Hipotesis Teori}

Hipotesis teori penelitian ini adalah: 
1. Faktor Sumber (Kredibilitas, Daya Tarik, Kekuatan) mempengaruhi proses perantara internal.

2. Faktor Pesan (Validitas, Aktualisasi, Kemasan Isi Pesan) mempengaruhi proses perantara internal.

3. Faktor Proses Perantara Internal mempengaruhi sikap mahasiswa

\section{METODE PENELITIAN}

Penelitian menggunakan pendekatan penelitian kuantitatif. Penelitian kuantitatif menurut anapiah Faisal (1995 : 22) adalah Suatu pendekatan yang dilakukan untuk mendapatkan data yang dapat diukur berupa angka-angka (kuantitatif), atau skor-skor secara empiris sebagai simbol atau lembaga sikap tertentu dari responden dengan aturanaturan penelitian yang berlaku. Jenis penelitian termasuk kedalam penelitian eksplanatif. Menurut Singarimbun \& Effendi (1995: 5) penelitian eksplanatif adalahPenelitian yang menjelaskan hubungan kausal antara variabel-variabel melalui pengujian hipotesa.

Data Penelitian ini diperoleh melalui survey menurut Singarimbun \& Effendi, (1995: 53) adalah penelitian yang mengambil sampel dari satu populasi dan menggunakan kuesioner sebagai alat pengumpulan data yang pokok

Unit penelitian adalah unit yang akan diteliti atau dianalisa (Singarimbun \& Effendi, 1995: 155). Unit analisis menunjukkan siapa atau apa yang mempunyai karakteristik yang akan diteliti, seperti individu, keluarga, desa dan sebagainya. Unit analisis dalam penelitian ini adalah mahasiwa dari Universitas atau Sekolah Tinggi di DKI Jakarta yang telah mendapatkan penyuluhan pajak dari pihak Dirjen Pajak.

Pelaksanaan penelitian ini dilakukan di Kantor Pusat Penyuluhan Pajak Di Jakarta, yang memberikan penyuluhan kepada beberapa Universitas dan Sekolah Tinggi di Jakarta. Universitas dan Sekolah Tinggi tersebut adalah Universitas Trisakti, Universitas Mercu Buana, Universitas Kristen Indonesia, STIE Nusantara dan Sekolah
Tinggi Ilmu Administrasi Mandala Indonesia (STIAMI). Jumlah populasinya adalah sebanyak 200 peserta penyuluhan. Kemudian sampel akan ditarik dengan menggunakan Simple Random Sampling. Adapun jumlah sampel penelitian ini berjumlah 134 orang

Kuesioner yang disebar berisi pernyataan-pernyataan dengan menggunakan metode Likert Summated Rating (LSR). Skala Likert berisi serangkaian pemyataan pendapat yang positif dan negatif tentang suatu konstruk. Setiap rangkaian disertai dengan skala yang menyandang lima atau tujuh poin respon (Bulaeng, 2004 : 106). Pada penelitian ini, peneliti menggunakan skala Likert dengan rangkaian lima titik pengukuran dengan 2 kutub adjective (positif-negatif), untuk membuat keputusan. Setiap item metode Likert diberi pilihan respon Uawaban) sebagai berikut:

\section{\begin{tabular}{|l|l|l|l|l|}
\hline STS & TS & R & S & SS \\
\hline
\end{tabular}}

Keterangan:

Respon Skor Nilai

STS Sangat Tidak Setuju 1

TS = Tidak Setuju 2

$\mathrm{R}=$ Ragu-ragu 3

$\mathrm{S}=$ Setuju 4

$\mathrm{SS}=$ Sangat Setuju 5

\section{Pengujian Hipotesa}

Pengujian terhadap tiga buah hipotesa yang diajukan dilakukan dengan menggunakan Path Analysis dengan bantuan software Amos. Metode ini dipilih karena terdapat variabel dependen (endogenous) yang menjadi variabel independen (exogenous) untuk variabel yang lainnya. Dengan kata lain terdapat variabel antara dalam model penelitian.

Adapun dasar pengambilan keputusan uji hipotesa adalah dengan membandingkan besamya $p$-value dengan level of significant sebesar 5\% (alpha 0,05). Jika p-value lebih kecil atau kurang dari alpha 0,05 berarti terdapat pengaruh yang signifikan antar kedua variabel. Demikian pula sebaliknya jika $p$ value lebih besar dari alpha 0,05 maka tidak terdapat pengaruh yang signifikan diantara kedua variabel. 
Ida Ri’aeni, Strategi Komunikasi Pemasaran Digital Pada Produk Kuliner Tradisional

Berikut ini adalah tabel rangkuman

analysis:

hasil penguji an dengan menggunakan path

Tabel 1. Hasil Analisa Path Analysis

\begin{tabular}{|l|l|l|}
\hline \multicolumn{1}{|c|}{ Hipotesa } & Beta & $\rho$-value \\
\hline $\begin{array}{l}\text { H1 : Sumber } \rightarrow \text { Variabel Antara (perhatian, pemahaman dan } \\
\text { penerimaan) }\end{array}$ & $-0,050$ & 0,605 \\
\hline $\begin{array}{l}\text { H2 : Pesan } \rightarrow \text { Variabel Antara (perhatian, pemahaman dan } \\
\text { penerimaan) }\end{array}$ & 0,533 & 0,000 \\
\hline $\begin{array}{l}\text { H3 : Variabel Antara (perhatian, pemahaman dan penerimaan) } \\
\rightarrow \text { Sikap }\end{array}$ & 0,575 &, 000 \\
\hline
\end{tabular}

Sumber: data d10/ah dengan Amos

\section{Hipotesa 1}

Bunyi hipotesa null (Ho) dan hipotesa alternatif (Ha) adalah sebagai berikut:

$\mathrm{H}_{\mathrm{o} 1}$ : Faktor sumber tidak mempengaruhi proses perantara internal

$\mathrm{H}_{\mathrm{al}}$ : Faktor sumber mempengaruhi proses perantara internal

Hasil pengolahan data seperti yang dirangkum pada tabel diatas, menunjukkan bahwa untuk hipotesa pertama $p$-value 0,605 lebih besar dari alpha 0,05 . Sehingga hipotesa observasi $\left(\mathrm{H}_{\mathrm{o} 1}\right)$, diterima. Artinya, faktor sumber tidak signifikan berpengaruh terhadap proses perantara internal.

\section{Hipotesa 2}

Bunyi hipotesa null (Ho) dan hipotesa alternatif (Ha) adalah sebagai berikut:

$\mathrm{H}_{02}$ : Faktor pesan tidak mempengaruhi Proses Perantara Internal

$\mathrm{H}_{\mathrm{a} 2}$ : Faktor pesan mempengaruhi Proses Perantara Internal

Hasil pengolahan data menunjukkan bahwa untuk hipotesa kedua p-value 0,000 lebih kecil dari alpha 0,05 . Sehingga hipotesa observasi (Ho2), ditolak. Artinya, terdapat pengaruh yang signifikan dari faktor pesan terhadap proses perantara internal. Nilai koefisien (beta) yang bertanda positif sebesar 0,533 menunjukkan bahwa pesan berpengaruh positif kuat terhadap proses perantara internal. Artinya semakin valid dan aktual materi yang disampaikan, serta isi pesan informatif, mudah dipahami, mudah diingat dan menarik dalam penyampaiannya maka khalayak akan semakin memperhatikan dan kemudian akan semakin memahami dan menerima materi yang diberikan oleh penyuluh setelah mendapatkan penyuluhan.

\section{Hipotesa 3}

Bunyi hipotesa null $\left(\mathrm{H}_{\mathrm{o}}\right)$ dan hipotesa alternatif $\left(\mathrm{H}_{\mathrm{a}}\right)$ adalah sebagai berikut:

$\mathrm{H}_{\mathrm{o} 3}$ : Proses perantara internal sebagai variabel antara tidak mempengaruhi sikap

$\mathrm{H}_{\mathrm{a} 3}$ : Proses perantara internal sebagai variabel antara mempengaruhi sikap

Hasil pengolahan data menunjukkan bahwa untuk hipotesa ketiga p-value 0,000 lebih kecil dari alpha 0,05. Sehingga hipotesa observasi (Ho3), ditolak. Artinya, terdapat pengaruh yang signifikan dari proses perantara internal terhadap sikap. Nilai koefisien (beta) yang bertanda positif sebesar 0,575 menunjukkan bahwa proses perantara internal berpengaruh positif kuat terhadap sikap. Artinya jika responden dalam hal ini adalah mahasiswa, semakin memperhatikan, memahami dan dapat menerima materi yang disampaikan penyuluh maka sikap mahasiswa akan semakin positif terhadap materi yang disampaikan dalam hal ini pajak, dan pada akhirnya mahasiswa akan percaya bahwa dengan membayar pajak memungkinkan terciptanya kesejahteraan bagi masyarakat.

\section{SIMPULAN}


Kesimpulan yang dapat diperoleh dari penelitian ini adalah sebagai berikut:

1. Dari hasil penelitian yang telah dilakukan dapat dilihat bahwa pada penelitian ini, pengaruh Faktor sumber yang terdiri dari kredibilitas (credibility), daya tarik (attractiveness), dan kekuatan (power) komunikator tidak berpengaruh terhadap sikap mahasiswa. Dari penelitian ini ditemukan bahwa pemyataan-pernyataan Responden terhadap kredibilitas penyuluh cukup baik. Ini terlihat dari pernyataanpemyataan bahwa menurut responden penyuluh memiliki pengetahuan yang lengkap, penyuluh menguasai materi yang disampaikan, penyuluh memiliki pengalaman dibidang perpajakan, penyuluh dapat dipercaya, penyuluh objektif dalam menyampaikan materi. Ini mengungkapkan bahwa kredibilitas penyuluh tinggi. Hal ini sesuai dengan penelitian yang dilakukan oleh Kelman dan Hovland (Petty \& Cacioppo, 1996: 63). Dalam penelitiannya mereka menemukan bahwa kredibilitas sumber yang tinggi tidak selalu menjamin bahwa isi pesan lebih persuasif.

Apabila dilihat dari pemyataan responden mengenai daya tarik penyuluh, pemyataan-pernyataan responden mengenai daya tarik penyuluh mengungkapkan bahwa responden menganggap bahwa daya tarik penyuluh biasa-biasa saja, karena dari semua pemyataan yang diberikan oleh responden tidak semuanya positif. Menurut Venus (2004 : 64) daya tarik tidak sepenuhnya menjamin khalayak akan menerima pesan yang disampaikan.

Dilihat dari pernyataan responden mengenai kekuatan sumber, terungkap bahwa responden menyatakan bahwa penyuluh kurang memiliki kekuatan atas diri responden, sedangkan menurut Kelman (Petty \& Cacioppo, 1996; 68) khalayak memberikan persetujuan publik lebih besar kepada komunikator yang memiliki kekuasaan dibanding kepada komunikator yang tidak memiliki kekuasaan.
2. Pada penelitian ini terdapat pengaruh yang signifikan dari faktor pesan terhadap Proses Perantara Internal. Pada penyuluhan yang dilakukan oleh Dirjen Pajak, Faktor Pesan yang terdiri dari Validitas isi pesn, Aktualisasi isi pesan, Kemasan isi pesan berpengaruh terhadap sikap rnahasiswa. Dimana dapat disimpulkan bahwa semakin valid dan aktual materi yang disampaikan, serta isi Pesan informatif, rnudah dipahami, mudah diingat dan menarik dalam penyampaiannya maka akan semakin mendapat perhatian mahasiswa. hal ini sesuai dengan pendapat Hovland (Petty \& Cacioppo, 1996: 69) bahwa agar dapat mempersuasi khalayak pesan tersebut harus diperhatikan, dipahami dan pada akhirnya sampai pada perubahan sikap.

3. Pada dasarnya penyuluhan pajak yang dilakukan oleh Dirjen Pajak dapat mempengaruhi sikap mahasiswa. Namun pada penelitian ini, hanya faktor pesan yang mempengaruhi sikap mahasiswa, sedangkan faktor sumber tidak memiliki pengaruh terhadap sikap mahasiswa. Sehingga dalam penyuluhan yang telah dilakukan oleh Dirjen Pajak, dapat disimpulkan bahwa sikap mahasiswa dibentuk melalui pesan yang diberikan.

Berdasarkan kajian teoritik, tinjauan empiris dan analisa data serta kesimpulan yang diperoleh, maka penelitian ini memberikan implikasi sebagai berikut:

- Implikasi Akademis

Dari hasil penelitian ini, terungkap bahwa dalam penyuluhan pajak yang dilakukan faktor sumber tidak mempengaruhi sikap mahasiswa. hal ini sejalan dengan pendapat dan penelitian yang dilakukan oleh:

Kelman dan Hovland (Petty \& Cacioppo, 1996: 63) yang dalam penelitiannya mengungkapkan bahwa kredibilitas sumber yang tinggi tidak selalu menjamin bahwa isi pesan lebih persuasif. Menurut Venus (2004: 64) daya tarik: tidak sepenuhnya menjamin khalayak akan 
menerima pesan yang disampaikan dan menurut Kelman (Petty \& Cacioppo, 1996; 68) khalayak memberikan persetujuan publik lebih besar kepada komunikator yang memiliki kekuasaan dibanding kepada komunikator yang tidak memiliki kekuasaan.

Dan dalam penyuluhan yang dilakukan yang mempengaruhi sikap mahasiswa adalah faktor pesan dimana validitas, al'tualisasi dan kemasan isi pesan mampu menarik perhatian mahasiswa yang kemudian membuat mahasiswa lebih paham terhadap pesan dan menerima pesan yang disampaikan dan pada akhirnya akan mempengaruhi sikap mahasiswa. Hal ini sejalan dengan pendapat Hovland dkk (Azwar, 2005 : 63) bahwa efek suatu komunikasi tertentu yang berupa perubahan sikap akan tergantung pada sejauh mana komunikasi itu diperhatikan, dipahami dan diterima.

- Implikasi Praktis

Bagi pemerintah, hasil penelitian ini diharapkan dapat dijadikan masukan dalam melakukan monitoring dan melakukan evaluasi terhadap penyuluhan pajak. Melalui penelitian ini terlihat bahwa hanya faktor pesan yang berpengaruh terhadap sikap mahasiswa, sedangkan faktor sumber yaitu penyuluh tidak berpengaruh secara signifikan terhadap sikap mahasiswa. Hal ini dapat menjadi masukan bagi pemerintah dalam hal ini Dirjen Pajak untuk membenahi sistem penyuluhannya. Karena penyuluhan pajak sebagai ujung tombak yang dilakukan untuk meningkatkan kesadaran masyarakat terutama kewajibannya dalam membayar pajak perluk pendekatan penyuluhan dan sosialisasi efektif agar dapat menciptakan masyarakat sadar pajak.

\section{DAFTAR PUSTAKA}

Ahmadi, Abu., (1991). Psikologi Sosial, Jakarta: PT. Rineka Cipta.

Azwar, Saifuddin., (1989). Sikap Manusia, Teori dan Pengukurannya, Jakarta: Pustaka Pelajar.
Belch, G.E., \& Belch, M.A., (1995). Introduction to Advertising and Promotion : An Integrated Marketing Communication Perspective. Chicago.

Effendy, O.U., (2003). Ilmu Komunikasi Teori dan Praktek, Bandung : PT. Remaja Rosdakarya.

Faisal, Sanapiah., (1995). Format-Format Penelitian Sosial, Jakarta : Reja Grafindo Persada.

Moriarty, S.E., (1991). Creative Advertising Theory and practic e, United States of America : Prentice-Hall. Inc.

Mulyana, D., (2004). Ilmu Komunikasi: Suatu Pengantar, Bandung: PT Remaja Rosdakarya.

Petty, R.E. \& Cacioppo, J.T., (1996) Attitud es and Persuasion : Classic and contemporary Approaches, United States of America : Westview Press, Inc.

Rakhmat, Jalaluddin., (2004). Metode Penelitian komunikasi, Bandung: PT. Remaja Rosdakarya.

Rejeki, S. N., \& Herawati, F. A, (1999). Dasar-Dasar Komunikasi Untuk Penyuluhan, Yogyakarta : Universitas Atmajaya.

Salamun, AT., (1990). Pajak, Citra dan Bebannya, Jakarta: PT. Rena Bina Pariwara.

Singarimbun, M. \& Effendy, S., (1995). Metode Penelitian Survey, Jakarta: LP3ES.

Venus, Antar., (2004). Manajemen Kampanye, Bandung: Simbiosa Rekatama Media. Weiss, H., Carol., (1972). Evaluation Research, USA: Prentice-Hall, Inc.

ARTIKEL JURNAL

Jurnal Perpajakan Indonesia, Volume 4 no 10, Juli 2005 